\title{
Effects of ripening time and combination of ovine and caprine milks on proteolysis of Picante cheese* $^{*}$
}

\author{
A. Cristina Freitas, ${ }^{a}$ J. Maria Fresno, ${ }^{b}$ Bernardo Prieto, ${ }^{b}$ F. Xavier Malcata ${ }^{a \dagger}$ \\ \& Javier Carballo ${ }^{c}$ \\ ${ }^{a}$ Escola Superior de Biotecnologia, Universidade Católica Portuguesa, 4200 Porto, Portugal \\ ${ }^{b}$ Departamento de Higiene y Tecnología de los Alimentos, Universidad de Léon, 24071 Léon, Spain \\ ${ }^{c}$ Area de Tecnología de los Alimentos, Facultad de Ciencias de Orense, Universidad de Vigo, 32004 Orense, Spain
}

\begin{abstract}
Proteolysis in Picante cheese was characterized by assaying for breakdown products throughout a 180 day ripening period using different combinations of ewe's and goat's milks. Parameters analysed were total nitrogen (TN), water-soluble nitrogen (WSN) and non-protein nitrogen (NPN) using Kjeldahl and spectrophotometric methods, and casein profile by electrophoresis. WSN at 180 days of ripening was $25-29 \%$ TN. The maximum NPN values were attained by 180 days of ripening and corresponded to $87 \%$ and $92 \%$ of the WSN in $0 \mathrm{C}$ and $100 \mathrm{C}$, respectively (where $i \mathrm{C}$ denotes a cheese manufactured with $i \%$ caprine milk). Statistically significant correlations were obtained between the various analytical methods of assay for nitrogen and ripening time. The spectrophotometric methods using either trinitrobenzenesulphonic acid or cadmium-ninhydrin proved satisfactory in assessing the ripening index (instead of the Kjeldahl method). Degradation of $\beta$-caseins at 180 days was $18.8,26.4,40.2,55.6$ and $36.5 \%$ for $0 \mathrm{C}$, $25 \mathrm{C}, 50 \mathrm{C}, 75 \mathrm{C}$ and $100 \mathrm{C}$, respectively. Degradation of $\alpha_{\mathrm{s}}$-caseins by 180 days was $35.9,40.2,81.8,93.0$ and $68.7 \%$ for $0 \mathrm{C}, 25 \mathrm{C}, 50 \mathrm{C}, 75 \mathrm{C}$ and $100 \mathrm{C}$, respectively. In general, a higher cheesemaking milk fraction of caprine milk was associated with higher amounts of $\gamma$-caseins.
\end{abstract}

\section{INTRODUCTION}

Picante cheese is a hard, spicy and heavily salted Portuguese traditional cheese. This type of cheese is manufactured at the farm level only from mixtures of ovine and caprine raw milks using commercial calf rennet without any starter culture, and is ripened for a long period of time (Cruz, 1945) in rooms without temperature or humidity control on layers of wheat straw and sand. As happens with other Portuguese traditional cheeses, scant data are available on biochemical and microbiological aspects of Picante cheese, and not until recently was information available on physicochemical and microbiological aspects of Picante cheese (Freitas $e t$

\footnotetext{
*Part of the data reported in this paper was presented as a poster communication entitled 'Proteolysis of Picante cheese: effects of ripening time and combination of ovine and caprine milks' at the EAAP-CIHEAM-FAO International Symposium: Basis of the Quality of Typical Mediterranean Animal Products, 29 September to 2 October 1996, Badajoz, Spain.* †To whom correspondence should be addressed.
}

$a l ., 1995,1996)$ and the influence of several technological parameters on its final characteristics (Freitas \& Malcata, 1996).

It is commonly accepted that cheese ripening is characterized by a network of complex physical, chemical and microbiological changes that affect the major components of the cheese matrix (Fernández-Salguero $t$ t al., 1989). Attempts to monitor this process have led to development of objective physicochemical indices which will eventually be useful in predicting the final quality of cheesc. For most hard and semi-hard cheese varieties, proteolysis is the most commonly used index of maturation (Farkye \& Fox, 1990) and it is also helpful in evaluating starter culture performance (Fox, 1989) because proteolysis strongly contributes to flavour and texture development (Guinee \& Wilkinson, 1992). Several techniques for measuring proteolysis in cheese have been developed and reviewed (Fox, 1989). In attempts to characterize the proteolysis in Picante cheese, several such methods were tested and compared (e.g. Kjeldahl protein determination, spectrophotometry and electro- 
phoresis). In addition, changes in the nitrogen fractions and intact casein in Picante cheese throughout a 180 day ripening period were followed and the effects of different proportions of ovine and caprine milks were ascertained.

\section{MATERIALS AND METHODS}

\section{Manufacture and sampling}

Five batches of mixtures of raw caprine and ovine milks from selected flocks at the ratios $0 / 100$ (caprine/ovine), $25 / 75,50 / 50,75 / 25$, and $100 / 0(\%, v / v)$ were prepared. These batches will be denoted hereafter as $0 \mathrm{C}, 25 \mathrm{C}$, $50 \mathrm{C}, 75 \mathrm{C}$, and $100 \mathrm{C}$, respectively. For each batch, 90 litres of milk were used to manufacture 20 cheeses according to traditional procedures (Freitas et al., 1996). Namely, milk was coagulated with calf rennet in liquid form (Fabre, Monza, Italy) without addition of a starter culture; the fresh cheeses were rubbed with dry salt after manufacture, and the cheeses ripened for a minimum of 4 months by appropriate piling up on straw and sand in maturation rooms.

Ten cheeses (two cheeses from each batch) were taken randomly and sent under refrigerated conditions to our laboratory for analysis at $0,9,25,40,55,83,110,140$ and 180 days of ripening (counted from the time that the first salting procedure was complete). The resulting experimental layout was thus in accordance with a (duplicated) $5 \times 9$ full factorial design. Samples of milk were also taken for analysis at $\mathbf{0}$ days.

\section{Compositional analyses}

Compositional analyses were done according to Richardson (1985) and Kosikowski (1982). The pH was measured with an electrode for solids (Ingold, Urdorf, Switzerland) connected to a potentiometer MicropH 2001 (Crison, Barcelona, Spain). The moisture content was determined gravimetrically after drying at $100^{\circ} \mathrm{C}$ in an oven (Memmert, Schwabach, Germany). The $\mathrm{NaCl}$ content was determined by the modified Volhard method using $\mathrm{AgNO}_{3}$ and KCNS (Merck, Darmstadt, Germany). Fat content was determined by the Van Gulik method (Anonymous, 1975) using 40\% $\mathrm{H}_{2} \mathrm{SO}_{4}$ and isoamyl alcohol (Pronalab, Lisbon, Portugal). Titrable acidity was determined according to AOAC (1990).

\section{Chemical analysis}

\section{Nitrogen fractions}

Total nitrogen (TN), water-soluble nitrogen (WSN) and non-protein nitrogen (NPN) were determined by the micro-Kjeldahl method using a Kjeltec System 1002 distilling unit (Tecator, Höganäs, Sweden). WSN was obtained via fractionation with water according to
Kuchroo \& Fox (1982), followed by acidification to $\mathrm{pH}$ 4.3 with $1.41 \mathrm{~N} \mathrm{HCl}$ (Pronalab). The NPN fraction, i.e. the nitrogen fraction soluble in $12 \%$ trichloroacetic acid (TCA), was prepared by adding $7.5 \mathrm{ml}$ of an aqueous solution of $48 \%(\mathrm{w} / \mathrm{v}$ ) TCA (Merck) to $22.5 \mathrm{ml}$ of WSE (water-soluble extract); the mixture was allowed to stand for $30 \mathrm{~min}$ at room temperature and then filtered through Whatman No. 42 filter paper (Maidstone, UK). Aliquots from WSN and NPN $(5 \mathrm{ml})$ were then analysed by the micro-Kjeldahl method.

The spectrophotometric method of Adler-Nissen (1979) with modifications, which comprises use of 2,4,6trinitrobenzenesulphonic acid (TNBS; Fluka Biochemika, Buchs, Switzerland) was also used to quantify the NPN and N-PTA fractions. The N-PTA fraction, i.e. the nitrogen fraction soluble in $5 \%$ phosphotungstic acid (PTA), was prepared by adding $14.0 \mathrm{ml}$ of an aqueous solution of $3.95 \mathrm{M} \mathrm{H}_{2} \mathrm{SO}_{4}$ (Pronalab) and $6 \mathrm{ml}$ of $33.3 \%(\mathrm{w} / \mathrm{v}$ ) PTA (Merck) to $20 \mathrm{ml}$ of WSE; the mixture was allowed to stand overnight at $4^{\circ} \mathrm{C}$ and subsequently filtered through Whatman No. 42 filter paper. In order to distinguish the NPN results obtained by the Kjeldahl method and by the spectrophotometric method, the former will hereafter be denoted as simply NPN and the latter as N-TCA. Samples $(0.2 \mathrm{ml})$ of NTCA or N-PTA were diluted in $0.1 \mathrm{M}$ sodium tetraborate or $4.0 \%$ sodium bicarbonate, respectively, and treated with $1.0 \mathrm{ml}$ of $0.1 \%$ TNBS. The mixtures were heated at $50^{\circ} \mathrm{C}$ for $1 \mathrm{~h} ; 2.5 \mathrm{ml}$ of $0.2 \mathrm{M} \mathrm{HCl}$ were added to quench the reaction, and were cooled to room temperature; absorbance was then read at $340 \mathrm{~nm}$.

The evolution of free amino acid nitrogen $\left(\mathrm{N}-\mathrm{NH}_{2}\right)$ was monitored according to Folkertsma \& Fox (1992) using the cadmium-ninhydrin reagent (Sigma, St Louis, MO, USA). A sample (25-50 $\mu$ l) of WSE was diluted to $1 \mathrm{ml}$ with distilled water; to this, $2 \mathrm{ml}$ of cadmium-ninhydrin reagent were added. The mixture was heated at $84^{\circ} \mathrm{C}$ for $5 \mathrm{~min}$, cooled to room temperature, and absorbance was read at $507 \mathrm{~nm}$.

Stock solutions of $2 \mathrm{mM}$ leucine (Sigma) and $1 \mathrm{mM}$ glycine (Merck) were used to obtain calibration curves for the cadmium-ninhydrin and the TNBS spectophotometric methods, respectively.

All analyses were perfomed in duplicate, and the average of each pair of determinations was used as a datum point.

\section{Casein degradation}

Degradation of casein was assayed by urea-polyacrylamide gel electrophoresis (PAGE) $(10.5 \% \mathrm{~T}, 4.8 \% \mathrm{C})$ according to the method of Andrews (1983) with modifications using a Protean II XI vertical slab-gel unit (Bio-Rad Laboratories, Watford, UK). The cheese samples were prepared according to Farkye et al. (1991), with modifications. The gels were stained with Coomassie Blue G-250 (Bio-Rad, Richmond, CA, USA) according to the method of Blakesley \& Boezi (1977). Ovine and caprine casein standards were purchased 
Table 1. Composition of ovine and caprine milks and mixtures thereof used for the manufacture of the various experimental cheeses

\begin{tabular}{lllllll}
\hline $\begin{array}{l}\text { Type of } \\
\text { cheese }\end{array}$ & $\begin{array}{l}\text { Cheese } \\
\text { milk }\end{array}$ & pH & $\begin{array}{c}\text { Acidity } \\
\left({ }^{\circ} \mathrm{D}\right)\end{array}$ & $\begin{array}{c}\text { Total fat } \\
(\%)\end{array}$ & $\begin{array}{c}\text { Casein } \\
(\%)\end{array}$ & $\begin{array}{c}\text { Density } \\
\left(\mathrm{g} \mathrm{cm}^{-3}\right)\end{array}$ \\
\hline $0 \mathrm{C}$ & Ovine & 6.72 & 30.0 & 5.80 & 4.47 & 1.036 \\
& Ovine & 6.71 & 29.0 & 6.00 & 4.40 & 1.035 \\
$25 \mathrm{C}$ & Caprine & 6.70 & 25.0 & 5.90 & 3.15 & 1.030 \\
& Mixture & 6.70 & 28.0 & 5.95 & 3.96 & 1.035 \\
& Ovine & 6.70 & 29.5 & 5.10 & 4.40 & 1.035 \\
$50 \mathrm{C}$ & Caprine & 6.62 & 23.0 & 5.30 & 3.70 & 1.028 \\
& Mixture & 6.65 & 26.5 & 5.20 & 3.95 & 1.033 \\
& Ovine & 6.65 & 29.0 & 5.30 & 4.20 & 1.036 \\
$75 \mathrm{C}$ & Caprine & 6.68 & 27.0 & 5.40 & 3.08 & 1.031 \\
& Mixture & 6.68 & 27.5 & 5.40 & 3.37 & 1.032 \\
$100 \mathrm{C}$ & Caprine & 6.62 & 22.5 & 6.10 & 3.20 & 1.031 \\
\hline
\end{tabular}

from Sigma. The evolution of the densitometric peak areas associated with the various caseins throughout the ripening time was quantitatively assessed by the software package Diversity One ${ }^{\times} 1.0$ (pdi, New York, NY, USA) after having duly scanned the electrophoresis gels.

All electrophoresis analyses were performed in duplicate.

\section{Sensorial analysis}

Cheeses ripened for 180 days were assessed organoleptically by a group of nine experienced panellists. Parameters assessed were form (0-4: 0 , very bad; 4 , very good), surface (0-4), texture (0-6) and flavour (0-6).

\section{Statistical analysis}

Linear relationships between the various methods of assessment of proteolysis with respect to ripening time and cheesemaking milk composition, were statistically evaluated; for each significant effect, the corresponding difference was determined by Scheffe's $F$ multiple comparison test at the 5\% significance level. All statistical analyses were carried out with the StatView software v.4.01 (Abacus Concepts, Berkeley, CA, USA).

\section{RESULTS AND DISCUSSION}

\section{Compositional characteristics}

The results of the compositional analyses of the milks used in the manufacture of the five batches of Picante cheese are summarized in Table 1 . Using a $t$-test, it was concluded that variations in $\mathrm{pH}$ were not significant between the averages for the ovine and caprine milks at the $5 \%$ level. The acidity values for ovine milk were higher than those for caprine milk, probably due to the higher content of casein in ovine milk. Conversely, the fat content of caprine milk was slightly above that of ovine milk

Table 2 summarizes the major compositional characteristics of the various experimental cheeses manufactured. The cheeses produced from caprine milk had the lowest moisture content during the early stages of

Table 2. Compositional characteristics of the various experimental cheeses

\begin{tabular}{|c|c|c|c|c|c|c|c|c|c|c|}
\hline & \multirow{2}{*}{$\begin{array}{l}\text { Type of } \\
\text { cheese }\end{array}$} & \multicolumn{9}{|c|}{ Ripening time (days) } \\
\hline & & 0 & 9 & 25 & 40 & 55 & 83 & 110 & 140 & 180 \\
\hline & $0 \mathrm{C}$ & 5.65 & 5.31 & 5.49 & 5.49 & 5.43 & 5.72 & 6.15 & 6.05 & 5.96 \\
\hline & $25 \mathrm{C}$ & 5.58 & 5.47 & 5.60 & 5.51 & 5.37 & 5.70 & 6.34 & 6.09 & 6.09 \\
\hline \multirow[t]{5}{*}{$\mathrm{pH}$} & $50 \mathrm{C}$ & 5.58 & 4.76 & 5.33 & 5.30 & 5.28 & 5.76 & 6.08 & 6.04 & 6.05 \\
\hline & $75 \mathrm{C}$ & 5.28 & 4.62 & 5.29 & 5.30 & 5.25 & 5.72 & 6.14 & 6.09 & 6.06 \\
\hline & $100 \mathrm{C}$ & 5.17 & 4.75 & 5.08 & 5.31 & 5.24 & 5.70 & 6.05 & 6.01 & 6.04 \\
\hline & $O C$ & 7.64 & 17.4 & 15.0 & 15.14 & 15.81 & 15.84 & 16.41 & 15.38 & 19.88 \\
\hline & $25 \mathrm{C}$ & 9.88 & 15.6 & 16.0 & 15.95 & 15.59 & 15.68 & 16.70 & 15.47 & 19.48 \\
\hline \multirow[t]{4}{*}{$\mathrm{NaCl}(\% \mathrm{TS})$} & $50 C$ & 8.85 & 14.7 & 15.5 & 15.99 & 16.53 & 16.95 & 16.12 & 16.58 & 19.79 \\
\hline & $75 \mathrm{C}$ & 8.31 & 16.5 & 14.0 & 15.06 & 15.02 & 16.14 & 16.03 & 14.95 & 18.80 \\
\hline & $100 \mathrm{C}$ & 6.82 & 16.5 & 15.2 & 15.04 & 14.95 & 16.75 & 15.51 & 14.47 & 19.61 \\
\hline & OC & 59.67 & 53.67 & 50.17 & 48.94 & 48.50 & 49.04 & 47.59 & 43.30 & 40.48 \\
\hline \multirow[t]{5}{*}{ Moisture content $(\%)$} & $25 \mathrm{C}$ & 59.90 & 51.37 & 49.93 & 50.21 & 49.84 & 48.54 & 47.41 & 43.84 & 40.49 \\
\hline & $50 \mathrm{C}$ & 57.74 & 52.25 & 50.29 & 51.23 & 49.92 & 49.96 & 47.68 & 44.81 & 40.28 \\
\hline & $75 \mathrm{C}$ & 57.27 & 50.75 & 50.28 & 47.81 & 48.46 & 49.62 & 47.42 & 43.69 & 38.84 \\
\hline & $100 \mathrm{C}$ & 55.99 & 49.37 & 49.20 & 49.95 & 48.23 & 49.36 & 46.56 & 42.42 & 40.03 \\
\hline & OC & 0.744 & 0.886 & 1.11 & 0.966 & 0.888 & 0.866 & 0.861 & 1.06 & 1.30 \\
\hline \multirow{5}{*}{$\begin{array}{l}\text { Titrable acidity } \\
\text { (g lactic acid per } \\
100 \text { g TS) }\end{array}$} & $25 \mathrm{C}$ & 0.705 & 0.711 & 0.980 & 1.04 & 0.949 & 0.908 & 0.968 & 0.967 & 1.40 \\
\hline & $50 \mathrm{C}$ & 1.30 & 1.34 & 1.33 & 1.38 & 1.155 & 0.895 & 0.824 & 1.22 & 1.21 \\
\hline & $75 \mathrm{C}$ & 0.965 & 1.02 & 1.37 & 1.34 & 1.399 & 1.209 & 0.938 & 1.07 & 1.34 \\
\hline & $100 \mathrm{C}$ & 1.37 & 1.6 & 1.69 & 1.63 & 1.385 & 1.075 & 1.00 & 1.10 & 1.31 \\
\hline & $0 \mathrm{C}$ & 17.25 & 20.50 & & 21.5 & & 26.00 & 26.25 & & 28.25 \\
\hline \multirow[t]{4}{*}{ Total fat (\%) } & $25 \mathrm{C}$ & 17.75 & 20.00 & & 23.0 & & 23.25 & 26.25 & & 29.25 \\
\hline & $50 \mathrm{C}$ & 20.25 & 21.50 & & 24.4 & & 25.00 & 27.00 & & 30.25 \\
\hline & $75 \mathrm{C}$ & 22.25 & 24.50 & & 25.0 & & 27.25 & 28.75 & & 32.75 \\
\hline & $100 \mathrm{C}$ & 23.75 & 26.25 & & 27.25 & & 27.25 & 29.55 & & 32.50 \\
\hline
\end{tabular}

TS, total solids. 
ripening; in general, a higher content in ovine milk led to a higher moisture content of the corresponding cheese. Table 1 indicates that the level of fat of both milk types was similar, but the level of casein was higher for ovine milk. Therefore, the observed differences in the moisture content of the cheeses may be attributed to the higher content in casein which leads to a higher water-holding capacity. This observation is in agreement with Mallatou et al. (1994) and Pappas et al. (1994), who reported that the moisture content of cheeses increases as the ratio of casein to fat in cheese milk increases. Such differences in moisture content tended, nevertheless, to vanish as ripening progressed.

Picante cheese is typically characterized by a high content of $\mathrm{NaCl}$, as was confirmed by Table 2 . The values for $\mathrm{NaCl}$ content at 0 days and 9 days of ripening were due to the fact that the first salting procedure is performed on the fresh cheese and the second salting procedure normally takes place after about 1 week of ripening; hence, a considerable increase in $\mathrm{NaCl}$ content is expected from 0 days to 9 days (as observed in Table 2). Throughout the ripening period and for the different types of cheese, the values of $\mathrm{NaCl}$ showed considerable variability; this is likely the result of the way salting is done (manually and in a completely empirical fashion) and to the several washes with tap water throughout the ripening period. The increase of $\mathrm{NaCl}$ content from 140 to 180 days was somewhat unexpected; this probably resulted from inadvertent use of a strong brine to wash the experimental cheeses that had reached that stage in ripening, as is sometimes done by local manufacturers (especially during summer) in response to topical contamination by insects.

The mean $\mathrm{pH}$ values were lower for the cheeses with a lower content in caprine milk. This observation disagrees with results reported for the mean $\mathrm{pH}$ values by Mallatou et al. (1994) in their study of Feta cheese, where five compositions in ovine and caprine milks similar to those used in our study were considered. The magnitude of the $\mathrm{pH}$ range for the various cheeses decreased throughout ripening, and by 83 days it was virtually nil. The $\mathrm{pH}$ of all cheeses decreased until 55 days and then increased until the end of ripening. A similar pattern of $\mathrm{pH}$ change was observed in Feta cheese manufactured with ovine milk (Alichanidis et al., 1984; Pappas et al., 1992). The lowest value of $\mathrm{pH}$ found for cheeses manufactured with caprine milk at 0 days could be attributed to the lower buffering capacity of caprine milk derived from a lower protein content (Simos et al., 1991), as can be concluded from inspection of Table 1.

The percentage dry matter increased by $47.6 \%$ for cheeses manufactured with ovine milk and by $36.3 \%$ for cheeses manufactured with caprine milk for the whole duration of the ripening period. These values are larger than those observed in Idiazabal cheese (22\%) (Ibáñez et al., 1995) for a similar ripening time (i.e. 180 days). Such large changes in total solids can be attributed to surface evaporation (Schlesser et al., 1992), especially because Picante cheese does not develop an actual rind, as well as to diffusion of salt towards the interior of the cheese throughout ripening (Abo El-Ella et al., 1988; Schroeder et al., 1988; Zorrilla \& Rubiolo, 1991).

With respect to total fat, higher contents were found in cheeses with higher contents of caprine milk, which correlates with the caprine milk fat content (see Table 1).

\section{Nitrogen fractions}

The results for the various nitrogen fractions throughout the ripening period for the different experimental cheeses are summarized in Table 3 . The average variations and corresponding standard deviations (throughout the whole 180 day ripening period) in total nitrogen as percentage of total solids were $5.51 \pm 0.11$ for the $0 \mathrm{C}$ cheeses, $5.14 \pm 0.13$ for the $25 \mathrm{C}$ cheeses, $4.78 \pm 0.19$ for the $50 \mathrm{C}$ cheeses, $4.69 \pm 0.20$ for the $75 \mathrm{C}$ cheeses, and $4.54 \pm 0.19$ for the $100 \mathrm{C}$ cheeses.

All nitrogen fractions showed significant increases during ripening. Levels of WSN reached $25-29 \%$ by 180 days, which were higher than those observed in Idiazabal cheese (16.6\%) (Ibáñez et al., 1995). Comparison with values observed in Majorero cheese, a goat's milk cheese with 33.8\% WSN (Fontecha et al., 1990), and in a semi-hard ewe's milk cheese with $23.8 \%$ WSN (Fontecha et al., 1994), both by 90 days of ripening, indicated that Picante cheese exhibits a moderate ripening extension index which, according to Furtado \& Partridge (1988), is a measure of moderate rennet activity. In fact, one of the major agents responsible for proteolysis during cheese ripening is residual coagulant retained in the curd after manufacture (de Jong, 1977; Visser, 1977a,c; O'Keeffe et al., 1978). The general pathway of proteolysis involves a primary limited breakdown of paracasein by residual rennet (and/or plasmin) to polypeptides, which are then further degraded by the proteinase/peptidase systems of starter or non-starter bacteria to peptides and amino acids (Kleter, 1977; Visser, 1977b,c; Wilkinson et al., 1992). According to Guinee \& Wilkinson (1992), changes in the rennet-to-casein ratio (due to changes in milk composition) are one of the possible process events that give rise to variations in residual rennet activity. In our case, as a result of the different volumetric fractions of ovine and caprine milks used in the manufacture of experimental cheeses, the rennet-to-casein ratio varied between the different types of cheese. This ratio increased with increase in the caprine milk content (relative increases of $13 \%$ for the $25 \mathrm{C}$ cheese and $38 \%$ for the $100 \mathrm{C}$ cheese, using the $0 \mathrm{C}$ cheese as a reference), and such an increase thus provides a possible justification for the observed differences in WSN.

Inspection of the ANOVA table reveals that ripening time and, to a lesser degree, milk composition were significant factors with regard to all nitrogen fractions. Scheffe's $F$ multiple comparison test revealed that the 
changes in WSN between 0 and 25 days and between 40 and 83 days of ripening were not significantly different at the $5 \%$ level, which is consistent with the higher increments in all nitrogen fractions in the second half of the normal ripening period (see Table 3). The pattern throughout the ripening period may be attributed chiefly to such factors as salt content and starter/nonstarter microflora. Inspection of the ANOVA table also indicates that the milk composition/ripening time interaction was statistically significant and that only cheeses manufactured with $0 \%$ and $25 \%$ caprine milk did not exhibit significant differences in terms of total soluble nitrogen.

The NPN measured by both methods (see Table 3) followed similar patterns with respect to WSN evolution, i.e. a slight increase in the beginning and a larger increase by the end of ripening. The maximum NPN values $87 \%$ and $92 \%$ of WSN in $0 \mathrm{C}$ and $100 \mathrm{C}$, respectively) were attained by 180 days of ripening. According to Desmazeaud \& Gripon (1977), the NPN fraction contains the free amino acids released from casein; in studies of six varieties of Blue cheese, Fernández-Salguero et al. (1989) claimed that, due to the high NPN content of the samples, most of the WSN fraction was accounted for by non-proteinaceous compounds. Based on values obtained for NPN (\%TN), it was concluded that Picante cheese is characterized by a high ripening depth index which, according to Furtado \& Partridge (1988), is an indication of a strong starter peptidase activity. Freitas et al. (1996) reported that enterococci and lactobacilli were the predominant groups of lactic acid bacteria identified throughout ripening; consequently, it appears that the metabolic action of such lactic acid bacteria leads to release of amino acids and short peptides. Multiple comparison tests showed that, in terms of ripening time, there was no statistical difference only between 0 and 9 days, whereas, in terms of milk composition, there was no statistical difference between $0 \mathrm{C}$ and $25 \mathrm{C}$, and between $50 \mathrm{C}, 75 \mathrm{C}$ and $100 \mathrm{C}$ with respect to NPN (\%TN).

In addition to studying the proteolysis in Picante cheese, the suitability of faster (and simpler) methods for estimating proteolysis as an alternative to the Kjeldahl method was assessed. This goal was important because Picante, as a minor traditional cheese, has generated little interest by researchers to date, and so the alternative methods have not yet been looked at. According to González de Llano et al. (1993), methods which use reagents that are specific for free amino groups are faster and easier than the Kjeldahl method. Table 4 tabulates the results of linear regression analyses for each of the ripening indices on ripening time. The values of the coefficients of determination $\left(r^{2}\right)$ were in all cases above 0.83 , which indicates that all methods considered were, in general, suitable for estimating the degree of ripening. However, the linear model provided the poorest fit when the classical Kjeldahl method was used to quantify WSN. Apparently, proteolysis in

Table 3. Indices of proteolysis in the various experimental cheeses

\begin{tabular}{|c|c|c|c|c|c|c|c|c|c|c|}
\hline \multirow[t]{2}{*}{ Nitrogen fraction } & \multirow{2}{*}{$\begin{array}{l}\text { Type of } \\
\text { cheese }\end{array}$} & \multicolumn{9}{|c|}{ Ripening time (days) } \\
\hline & & 0 & 9 & 25 & 40 & 55 & 83 & 110 & 140 & 180 \\
\hline \multirow[t]{5}{*}{$\mathrm{WSN}^{a}(\% \mathrm{TN})$} & $0 \mathrm{C}$ & 10.9 & 11.3 & 11.8 & 12.1 & 10.5 & 13.8 & 15.6 & 24.0 & 25.2 \\
\hline & $25 \mathrm{C}$ & 11.4 & 12.4 & 11.6 & 12.1 & 12.9 & 12.1 & 16.3 & 22.9 & 25.9 \\
\hline & $50 \mathrm{C}$ & 13.4 & 12.5 & 12.8 & 15.7 & 14.6 & 14.2 & 19.6 & 26.3 & 27.2 \\
\hline & $75 \mathrm{C}$ & 13.7 & 13.3 & 13.8 & 14.0 & 17.1 & 17.0 & 22.0 & 26.8 & 27.1 \\
\hline & $100 \mathrm{C}$ & 12.9 & 12.3 & 10.2 & 14.3 & 11.9 & 12.3 & 17.1 & 25.8 & 28.9 \\
\hline \multirow[t]{5}{*}{$\mathrm{NPN}^{a}(\% \mathrm{TN})$} & $0 \mathrm{C}$ & 3.03 & 3.65 & 4.78 & 5.80 & 6.48 & 9.15 & 12.9 & 18.2 & 21.8 \\
\hline & $25 \mathrm{C}$ & 2.91 & 3.42 & 3.77 & 5.64 & 7.28 & 9.96 & 12.0 & 18.2 & 22.5 \\
\hline & $50 \mathrm{C}$ & 4.37 & 4.62 & 4.72 & 6.50 & 7.54 & 10.8 & 15.9 & 22.8 & 23.4 \\
\hline & $75 \mathrm{C}$ & 4.30 & 4.05 & 4.83 & 5.94 & 7.53 & 11.7 & 15.5 & 23.0 & 25.0 \\
\hline & $100 \mathrm{C}$ & 4.23 & 3.11 & 4.93 & 4.62 & 7.97 & 10.7 & 16.7 & 22.7 & 26.6 \\
\hline \multirow{5}{*}{$\begin{array}{l}12 \% \mathrm{TCA}^{\mathrm{T}} \mathrm{N}^{b} \\
\left(\mathrm{mmol}_{\text {eq.Gly }} \mathrm{g}^{-1}\right. \\
\text { cheese) }\end{array}$} & $0 \mathrm{C}$ & 3.25 & 17.3 & 22.7 & 36.3 & 56.7 & 87.3 & 111 & 176 & 202 \\
\hline & $25 \mathrm{C}$ & 3.15 & 2.14 & 14.7 & 15.3 & 22.1 & 47.0 & 84.5 & 114 & 195 \\
\hline & $50 \mathrm{C}$ & 11.4 & 18.1 & 21.0 & 40.9 & 51.5 & 83.1 & 113 & 162 & 197 \\
\hline & $75 \mathrm{C}$ & 3.49 & 12.9 & 19.4 & 39.9 & 60.5 & 80.5 & 119 & 154 & 203 \\
\hline & $100 \mathrm{C}$ & 5.82 & 11.2 & 13.7 & 20.5 & 41.2 & 59.7 & 112 & 159 & 202 \\
\hline \multirow{5}{*}{$\begin{array}{l}5 \% \mathrm{PTA} \mathrm{N}^{b} \\
\text { (mmol }_{\text {eq.Gly }} \mathrm{g}^{-1} \\
\text { cheese) }\end{array}$} & OC & 2.38 & 4.93 & 14.7 & 17.1 & 21.0 & 31.4 & 40.6 & 80.3 & 113 \\
\hline & $25 \mathrm{C}$ & 4.29 & 10.2 & 11.5 & 20.6 & 21.9 & 26.5 & 40.0 & 80.6 & 103 \\
\hline & $50 \mathrm{C}$ & 4.24 & 6.31 & 8.29 & 15.2 & 28.2 & 32.4 & 51.9 & 93.4 & 109 \\
\hline & $75 \mathrm{C}$ & 1.73 & 8.77 & 15.8 & 22.1 & 30.5 & 40.0 & 63.2 & 88.4 & 119 \\
\hline & $100 \mathrm{C}$ & 1.40 & 5.44 & 2.65 & 13.2 & 20.9 & 32.3 & 59.0 & 91.7 & 125 \\
\hline \multirow{5}{*}{$\begin{array}{l}\mathrm{NH}_{2}-\mathrm{N}^{c} \\
\quad\left(\mathrm{mmol}_{\text {eq. Leu }} \mathrm{g}^{-1}\right. \\
\text { cheese) }\end{array}$} & OC & 3.08 & 4.40 & 7.09 & 11.1 & 13.5 & 25.3 & 31.7 & 48.3 & 69.05 \\
\hline & $25 \mathrm{C}$ & 2.92 & 3.66 & 6.01 & 7.51 & 12.9 & 17.8 & 31.7 & 47.5 & 67.3 \\
\hline & $50 \mathrm{C}$ & 4.93 & 6.05 & 6.77 & 9.14 & 14.1 & 19.4 & 29.9 & 54.0 & 72.6 \\
\hline & $75 \mathrm{C}$ & 4.82 & 5.54 & 6.46 & 10.0 & 15.0 & 23.4 & 32.6 & 52.4 & 94.5 \\
\hline & $100 \mathrm{C}$ & 4.15 & 4.58 & 4.77 & 14.0 & 21.2 & 21.1 & 46.1 & 90.3 & 102 \\
\hline
\end{tabular}

${ }^{a}$ Determined by the micro-Kjeldahl method.

${ }^{b}$ Determined by the TNBS spectrophotometric method.

${ }^{c}$ Determined by the cadmium-ninhydrin spectrophotometric method. 
Picante is relatively slow during early stages of ripening and faster at later stages, suggesting a (tentative) quadratic relationship between the values of WSN (\%TN) and time. As expected, higher correlation coefficients were achieved with a second-degree polynomial; however, the quadratic term could not be justified from a statistical point of view at the $5 \%$ level of significance. Regression of the amino acid nitrogen contents (i.e. 5\% PTA-N and $\mathrm{NH}_{2}-\mathrm{N}$ ) obtained by the two spectophotometric methods was satisfactory (see Table 4). According to Jarrett et al. (1982), although not perfect, measurements of PTA-N by reaction with TNBS probably lead to the best method of quantification of total amino nitrogen; Doi et al. (1981) claimed that cadmium-ninhydrin is much more reactive with the amino group of free amino acids than with the amino group of small peptides, and so is a suitable method for monitoring terminal stages of proteolysis in cheese (Folkertsma \& Fox, 1992).

The ripening indices of Picante cheese were also compared with the reference index $(\mathrm{WSN} / \mathrm{TN} \times 100)$ in order to determine whether any of them could be used to replace this classical index. Table 5 summarizes the parameter values for the linear regression equations. The $r^{2}$ values were higher than 0.84 in all cases; these results agree with those reported by González de Llano et al. (1993). The mean values and standard deviation of $r^{2}$ for the $12 \%$ TCA-N, 5\% PTA-N, and $\mathrm{NH}_{2}-\mathrm{N}$ were $0.915 \pm 0.020,0.940 \pm 0.017$ and $0.918 \pm 0.044$, respectively. These values indicate again that the spectophotometric methods using either TNBS or cadmiumninhydrin are good substitutes for the Kjeldahl method as measures of the ripening indices. Furthermore, results pertaining to several other varieties of cheese indicate that methods which evaluate free amino groups generate more information about the extension of proteolysis in cheese than methods that assess plain total nitrogen (Ardö \& Meisel, 1991).

\section{Casein degradation}

The electrophoretograms for caseins in the $0 \mathrm{C}$ and $100 \mathrm{C}$ cheeses throughout ripening are depicted in Figs 1 and 2, respectively. The changes in peak areas of the $\alpha_{s^{-}}, \beta$ and $\gamma$-caseins throughout ripening for the different experimental cheeses are depicted in Fig. 3.

The $\alpha_{\mathrm{s}}$ - and $\beta$-casein contents decreased with ripening time with respect to those at 0 days as a consequence of the action of residual rennet (as explained before), combined with the action of hydrolytic enzymes

Table 4. Parameter values, and corresponding standard deviation (SD), obtained by linear regression of proteolysis indices (NF) on ripening time $\left(t_{R}\right)$, and associated correlation coefficient $\left(r^{2}\right)$

\begin{tabular}{|c|c|c|c|c|}
\hline \multirow[t]{2}{*}{ Nitrogen fraction } & \multirow[t]{2}{*}{ Type of cheese } & \multicolumn{3}{|c|}{$\mathrm{NF}=a+b t_{\mathrm{R}}$} \\
\hline & & $a \pm \mathrm{SD}$ & $b \pm \mathrm{SD}$ & $r^{2}$ \\
\hline & $0 \mathrm{C}$ & $9.027 \pm 0.842$ & $0.084 \pm 0.009$ & 0.841 \\
\hline & $25 \mathrm{C}$ & $9.569 \pm 0.832$ & $0.080 \pm 0.009$ & 0.831 \\
\hline \multirow[t]{5}{*}{$\mathrm{WSN}^{a}(\% \mathrm{TN})$} & $50 \mathrm{C}$ & $11.225 \pm 0.796$ & $0.086 \pm 0.009$ & 0.861 \\
\hline & $75 \mathrm{C}$ & $12.085 \pm 0.559$ & $0.087 \pm 0.005$ & 0.928 \\
\hline & $100 \mathrm{C}$ & $9.386 \pm 1.140$ & $0.095 \pm 0.012$ & 0.787 \\
\hline & $0 \mathrm{C}$ & $1.887 \pm 0.414$ & $0.107 \pm 0.005$ & 0.973 \\
\hline & $25 \mathrm{C}$ & $1.617 \pm 0.398$ & $0.111 \pm 0.004$ & 0.976 \\
\hline \multirow[t]{4}{*}{$\mathrm{NPN}^{a}(\% \mathrm{TN})$} & $50 \mathrm{C}$ & $2.523 \pm 0.635$ & $0.121 \pm 0.007$ & 0.947 \\
\hline & $75 \mathrm{C}$ & $2.116 \pm 0.606$ & $0.129 \pm 0.007$ & 0.960 \\
\hline & $100 \mathrm{C}$ & $1.425 \pm 0.642$ & $0.138 \pm 0.007$ & 0.961 \\
\hline & $0 \mathrm{C}$ & $-2.538 \pm 3.630$ & $1.142 \pm 0.039$ & 0.981 \\
\hline \multirow[t]{5}{*}{$12 \%$ TCA-N $^{b}\left(\mathrm{mmol}_{\text {eq.Gly }} \mathrm{g}^{-1}\right.$ cheese) } & $25 \mathrm{C}$ & $-16.970 \pm 6.487$ & $1.013 \pm 0.070$ & 0.928 \\
\hline & $50 \mathrm{C}$ & $0.872 \pm 3.012$ & $1.073 \pm 0.033$ & 0.985 \\
\hline & $75 \mathrm{C}$ & $-2.453 \pm 2.097$ & $1.113 \pm 0.023$ & 0.993 \\
\hline & $100 \mathrm{C}$ & $-11.929 \pm 5.193$ & $1.140 \pm 0.056$ & 0.960 \\
\hline & $0 \mathrm{C}$ & $-5.204 \pm 4.000$ & $0.580 \pm 0.043$ & 0.918 \\
\hline \multirow[t]{5}{*}{$5 \%$ PTA-N $^{b}\left(\right.$ mmol $_{\text {eq.Gly }} \mathrm{g}^{-1}$ cheese $)$} & $25 \mathrm{C}$ & $-2.247 \pm 3.795$ & $0.528 \pm 0.041$ & 0.911 \\
\hline & $50 \mathrm{C}$ & $-4.826 \pm 3.305$ & $0.612 \pm 0.036$ & 0.948 \\
\hline & $75 \mathrm{C}$ & $-1.882 \pm 2.079$ & $0.633 \pm 0.023$ & 0.980 \\
\hline & $100 \mathrm{C}$ & $-10.555 \pm 3.596$ & $0.696 \pm 0.039$ & 0.952 \\
\hline & $0 \mathrm{C}$ & $-1.864 \pm 1.570$ & $0.359 \pm 0.017$ & 0.965 \\
\hline \multirow{4}{*}{$\mathrm{NH}_{2}-\mathrm{N}^{c}\left(\mathrm{mmol}_{\text {eq. Leu }} \mathrm{g}^{-1}\right.$ cheese $)$} & $25 \mathrm{C}$ & $-3.015 \pm 2.038$ & $0.352 \pm 0.022$ & 0.940 \\
\hline & $50 \mathrm{C}$ & $-2.589 \pm 2.464$ & $0.374 \pm 0.027$ & 0.924 \\
\hline & $75 \mathrm{C}$ & $-5.179 \pm 3.660$ & $0.454 \pm 0.040$ & 0.891 \\
\hline & $100 \mathrm{C}$ & $-7.206 \pm 4.171$ & $0.584 \pm 0.045$ & 0.911 \\
\hline
\end{tabular}

${ }^{a}$ Determined by the micro-Kjeldahl method.

${ }^{b}$ Determined by the TNBS spectrophotometric method.

'Determined by the cadmium-ninhydrin spectrophotometric method. 
released by microorganisms present in cheese (Fontecha et al., 1994). Identification of bands resolved by ureaPAGE electrophoresis of Picante cheese samples posed, however, several problems due to the mixture of ovine and caprine milks in their composition. According to Jaubert \& Martin (1992), the caseins in ruminant milks, which account for $83 \%$ (ovine) to $77 \%$ (caprine) of the overall protein, consist of four proteins $\left(\alpha_{s 1^{-}}, \alpha_{s 2^{-}}, \beta-\right.$ and $\kappa$;-caseins). In addition to total casein content, the relative proportions of each casein are also characteristic of the species: the $\alpha_{\mathrm{s} 1^{-}}, \alpha_{\mathrm{s} 2^{-}}, \beta$ - and $\kappa$;-caseins exist in ovine milk in the approximate proportions $2: 2: 5: 1$, respectively, whereas in caprine milk their proportions are 1:2:5:2, respectively (Assenat, 1985; Remeuf \& Lenoir, 1986). In Picante cheeses manufactured either with ovine milk or with caprine milk, two bands could be distinguished in the electrophoretograms (see Figs 1 and 2 ) in the $\beta$-casein electrophoretic region (which might thus correspond to $\beta_{2^{-}}$and $\beta_{1}$-caseins). In terms of bands in the electrophoretic region of $\alpha_{\mathrm{s}}$-caseins, three bands could be clearly distinguished in the $0 C$ cheese (corresponding probably to $\alpha_{\mathrm{s} 3^{-}}, \alpha_{\mathrm{s} 2^{-}}$and $\alpha_{\mathrm{s} 1}$-caseins), whereas in the $100 \mathrm{C}$ cheese only two bands could be clearly perceived (corresponding probably to $\alpha_{\mathrm{s} 2^{-}}$and $\alpha_{\mathrm{s} 1}$-caseins). In electrophoretograms of cheeses manufactured from mixtures of both milks (not shown), three bands corresponding to $\alpha_{\mathrm{s}}$-caseins were observed in $25 \mathrm{C}$, whereas only two bands appeared in $50 \mathrm{C}$ and $75 \mathrm{C}$ cheeses.
High molecular weight peptides (with mobilities similar to $\gamma$-caseins) were present in all types of cheese. The $\gamma$-caseins, which are formed on hydrolysis of $\beta$-caseins by indigenous plasmin (Noomen, 1978; Richardson \& Pearce, 1981; Grufferty \& Fox, 1988a,b), increased in concentration in all experimental cheeses during ripening, and up to four bands could be identified in their typical electrophoretic region.

The extent of breakdown of $\alpha_{\mathrm{s}^{-}}$and $\beta$-caseins, expressed as relative percentage of peak areas at 0 days, varied with the composition of the milk used. Higher resistance of $\beta$-caseins to enzymatic hydrolysis compared with $\alpha_{\mathrm{s}}$-caseins was observed among the various cheeses. These observations are consistent with those reported by Marcos et al. (1976) pertaining to several different types of cheese manufactured with caprine, ovine and bovine milks and coagulated with animal and plant rennets. The extent of degradation of $\beta$-caseins by 180 days were $18.8,26.4,40.2,55.6$ and $36.5 \%$ for the $0 \mathrm{C}, 25 \mathrm{C}, 50 \mathrm{C}, 75 \mathrm{C}$ and $100 \mathrm{C}$ cheeses, respectively. In terms of $\alpha_{\mathrm{s}}$-caseins, the extents of degradation were $35.9,40.2,81.8,93.0$ and $68.7 \%$ for the $0 \mathrm{C}, 25 \mathrm{C}, 50 \mathrm{C}$, $75 \mathrm{C}$ and $100 \mathrm{C}$ cheeses, respectively. Inspection of Fig. 3 suggests unexpected variability in terms of peak areas of caseins, especially $\alpha_{s}$-caseins in the $75 \mathrm{C}$ cheese. Applications of different amounts of $\mathrm{NaCl}$ (see Table 2) to the fresh cheeses, which thus lead to different degrees of protein loss during syneresis of whey and different intrinsic rates of enzymatic breakdown of proteins by

Table 5. Parameter values, and corresponding standard deviation (SD), obtained by linear regression of the proteolysis indices (NF) on the reference index (WSN/TN $\times 100$ ), and associated correlation coefficient $\left(r^{2}\right)$

\begin{tabular}{|c|c|c|c|c|}
\hline \multirow[t]{2}{*}{ Nitrogen fraction } & \multirow[t]{2}{*}{ Type of cheese } & \multicolumn{3}{|c|}{$\mathrm{NF}=a+b(\mathrm{WSN} / \mathrm{TN} \times 100)$} \\
\hline & & $a \pm \mathrm{SD}$ & $b \pm \mathrm{SD}$ & $r^{2}$ \\
\hline & $O C$ & $-7.697 \pm 1.200$ & $1.147 \pm 0.075$ & 0.936 \\
\hline & $25 \mathrm{C}$ & $-9.068 \pm 1.556$ & $1.216 \pm 0.097$ & 0.908 \\
\hline \multirow[t]{4}{*}{$\mathrm{NPN}^{a}(\% \mathrm{TN})$} & $50 \mathrm{C}$ & $-11.399 \pm 1.432$ & $1.298 \pm 0.079$ & 0.944 \\
\hline & $75 \mathrm{C}$ & $-14.930 \pm 1.134$ & $1.433 \pm 0.060$ & 0.973 \\
\hline & $100 \mathrm{C}$ & $-8.508 \pm 2.075$ & $1.223 \pm 0.120$ & 0.867 \\
\hline & OC & $-100.996 \pm 15.217$ & $11.792 \pm 0.954$ & 0.908 \\
\hline \multirow{5}{*}{$12 \% \mathrm{TCA}^{\mathrm{T}} \mathrm{N}^{b}\left(\mathrm{mmol}_{\text {eq.Gly }} \mathrm{g}^{-1}\right.$ cheese $)$} & $25 \mathrm{C}$ & $-119.592 \pm 14.076$ & $11.441 \pm 0.873$ & 0.915 \\
\hline & $50 \mathrm{C}$ & $-116.154 \pm 15.468$ & $11.147 \pm 0.851$ & 0.915 \\
\hline & $75 \mathrm{C}$ & $-142.762 \pm 13.611$ & $11.998 \pm 0.714$ & 0.946 \\
\hline & $100 \mathrm{C}$ & $-95.945 \pm 15.464$ & $10.216 \pm 0.890$ & 0.891 \\
\hline & OC & $-59.283 \pm 7.158$ & $6.352 \pm 0.449$ & 0.926 \\
\hline \multirow[t]{5}{*}{$5 \%$ PTA-N ${ }^{b}$ (mmol eq.Gly $\mathrm{g}^{-1}$ cheese) } & $25 \mathrm{C}$ & $-58.787 \pm 5.135$ & $6.163 \pm 0.319$ & 0.959 \\
\hline & $50 \mathrm{C}$ & $-76.013 \pm 6.663$ & $6.611 \pm 0.366$ & 0.953 \\
\hline & $75 \mathrm{C}$ & $-82.203 \pm 8.065$ & $6.851 \pm 0.423$ & 0.942 \\
\hline & $100 \mathrm{C}$ & $-63.865 \pm 8.245$ & $6.360 \pm 0.475$ & 0.918 \\
\hline & OC & $-33.433 \pm 4.675$ & $3.803 \pm 0.293$ & 0.913 \\
\hline \multirow{4}{*}{$\mathrm{NH}_{2}-\mathrm{N}^{c}\left(\mathrm{mmol}_{\text {eq.Leu }} \mathrm{g}^{-1}\right.$ cheese) } & $25 \mathrm{C}$ & $-39.263 \pm 3.914$ & $4.014 \pm 0.243$ & 0.945 \\
\hline & $50 \mathrm{C}$ & $-46.492 \pm 4.714$ & $4.065 \pm 0.259$ & 0.939 \\
\hline & $75 \mathrm{C}$ & $-62.062 \pm 10.031$ & $4.874 \pm 0.526$ & 0.843 \\
\hline & $100 \mathrm{C}$ & $-55.146 \pm 5.532$ & $5.525 \pm 0.319$ & 0.949 \\
\hline
\end{tabular}

${ }^{a}$ Determined by the micro-Kjeldahl method.

${ }^{b}$ Determined by the TNBS spectrophotometric method.

'Determined by the cadmium-ninhydrin spectrophotometric method. 


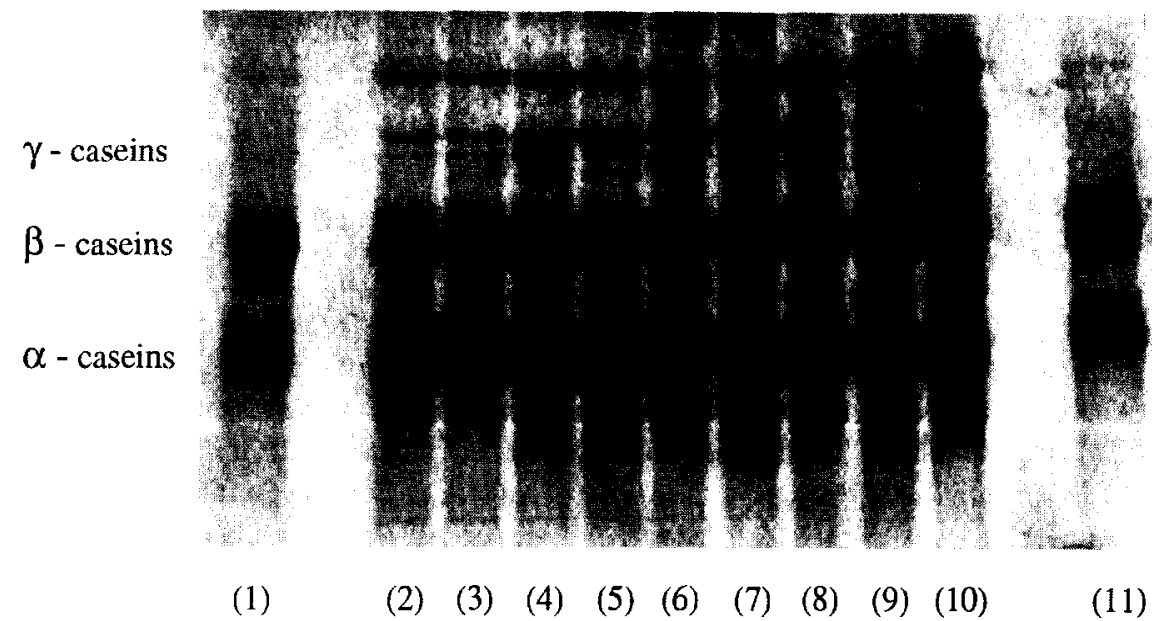

Fig. 1. Electrophoretogram for the cascin fraction obtained by urea-PAGE in $0 \mathrm{C}$ cheeses $(100 \%$ ovine milk) at 0 (2), 9 (3), 25 (4), $40(5), 55(6), 83(7), 110(8), 140(9)$ and 180 days (10) of ripening, and for the ovine casein standard (1 and 11).

residual rennet (Guinee \& Fox, 1993), are likely responsible (at least partially) for the aforementioned variability of casein breakdown.

The electrophoretically visible degradation products from $\alpha_{\mathrm{s}}$-caseins (i.e. pre- $\alpha_{\mathrm{s}}$-caseins) yielded thinner bands than those from $\beta$-caseins (i.e. $\gamma$-caseins). According to Marcos et al. (1978), this is probably due to their greater susceptibility to further hydrolysis or to differences in their dye-binding capacities. Inspection of Figs 1 and 2 shows that the intensity of the bands corresponding to $\gamma$-caseins increased, whereas that of the bands associated with the pre- $\alpha_{\mathrm{s}}$-caseins decreased, throughout ripening. The effect of milk composition was also reflected in the presence of $\gamma$-caseins throughout ripening: higher content in caprine milk led to higher increases in their concentrations. This observation is consistent with degradation data relating to $\beta$-casein (with the exception of the $100 \mathrm{C}$ cheese).

In the electrophoretograms of the different types of cheese, one (or two) bands located between the electrophoretic region corresponding to $\beta$ - and $\alpha_{\mathrm{s}}$-caseins could be detected. These bands are especially visible in the last three sampling points, and are possibly degradation products of $\beta$-casein. Mora \& Marcos (1981) reported a similar band in an ovine cheese and claimed that it corresponded to products of degradation of $\beta$ casein.

\section{Sensorial analysis}

The results of organoleptic assessment are summarized in Table 6. The appearance parameters (surface and form) of cheeses were rated as quite satisfactory by the taste panel (all scores were above 3 in a $0-4$ scale). Texture and flavour scores were also considered quite acceptable by the taste panels (the mean values by the end of ripening were above 4 in a $0-6$ scale). The effect of composition of the milk mixture was not statistically significant in terms of the organoleptic parameters analysed; however, both $75 \mathrm{C}$ and $100 \mathrm{C}$ cheeses obtained the highest scores in terms of texture and flavour (see Table 6).

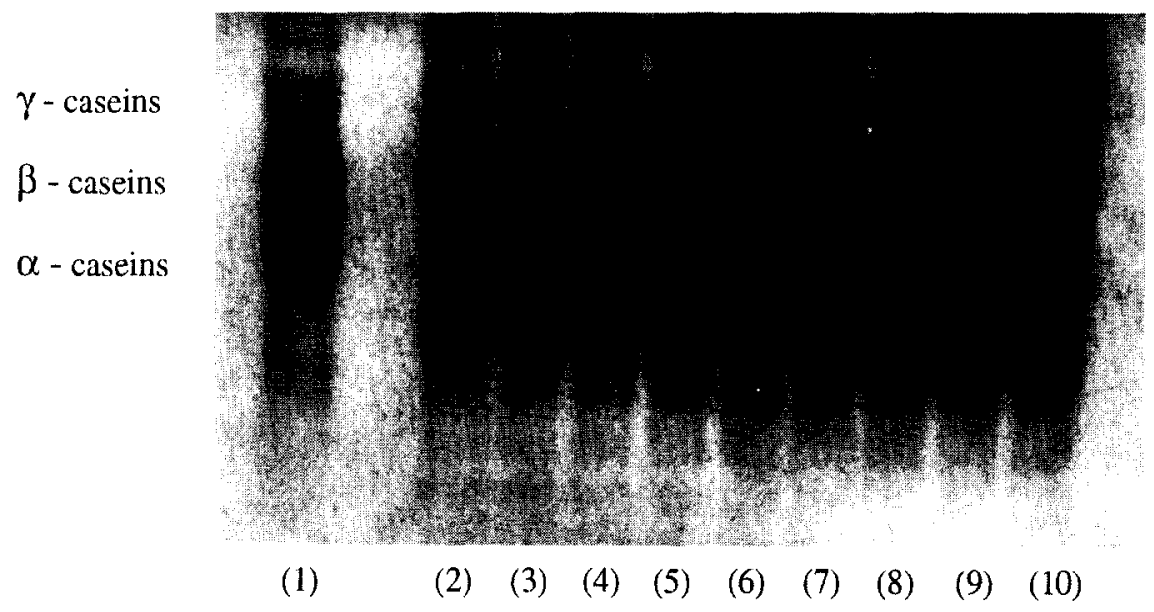

Fig. 2. Electrophoretogram for the casein fraction obtained by urea-PAGE in $100 \mathrm{C}$ cheeses (100\% caprine milk) at 0 (2), 9 (3), 25 (4), $40(5), 55(6), 83(7), 110(8), 140(9)$, and 180 days (10) of ripening, and for the caprine casein standard (1). 

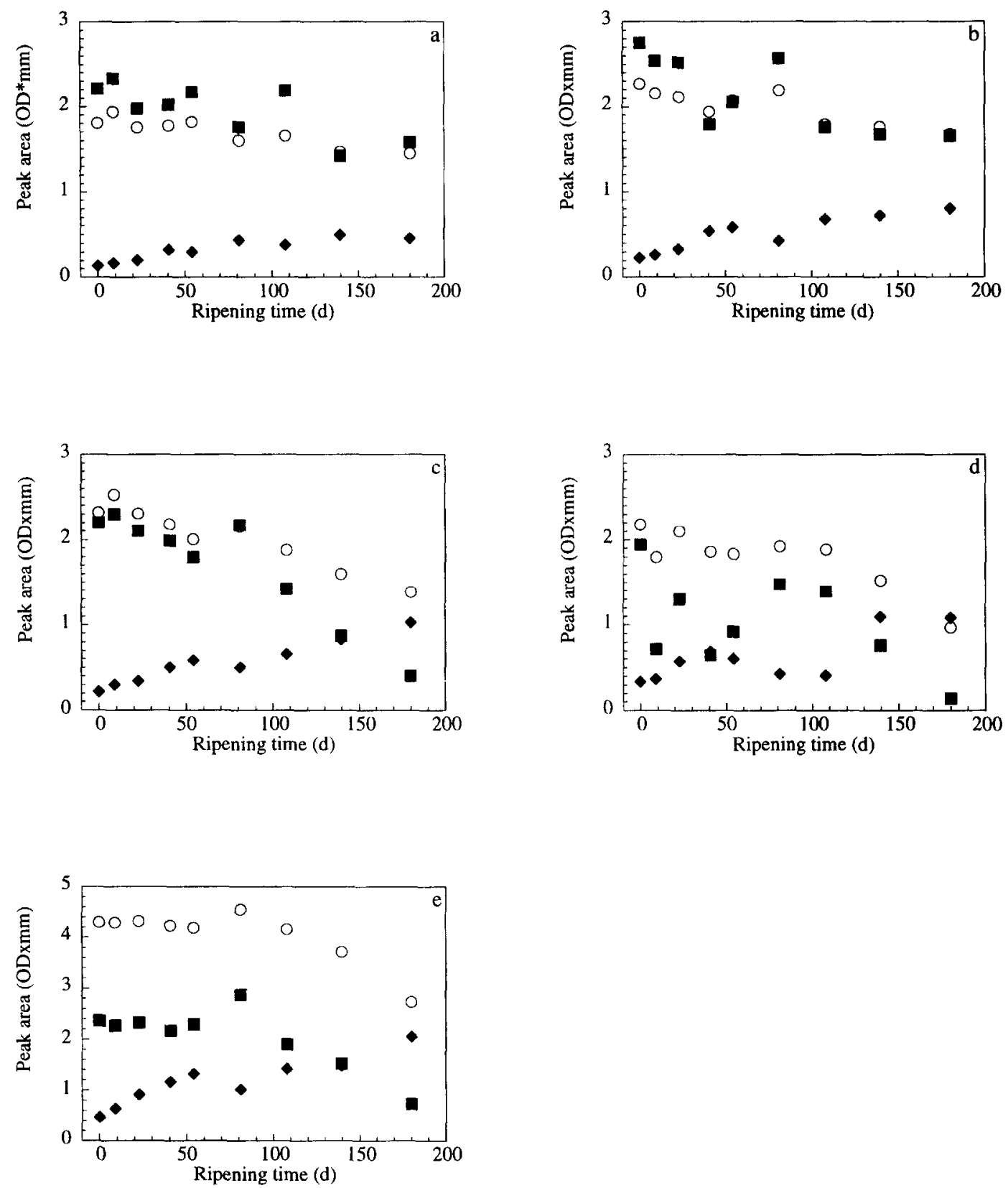

Fig. 3. Evolution of peak areas of $\gamma-(\bullet), \beta-(O)$ and $\alpha_{\mathrm{s}}$-caseins $(\mathbb{Q})$ throughout the ripening period for: (a) $0 \mathrm{C}$ cheese. Standard error of the mean (SEM) for $\gamma$-casein is 0.053 , SEM for $\beta$-casein is 0.223 , and SEM for $\alpha_{\mathrm{s}}$-casein is 0.268 ; (b) 25C cheese. SEM for $\gamma$-casein is 0.072 , SEM for $\beta$-casein is 0.085 , and SEM for $\alpha_{\mathrm{s}}$-casein is 0.125 ; $50 \mathrm{C}$ cheese. SEM for $\gamma$-casein is 0.073 , SEM for $\beta$-casein is 0.271 , and SEM for $\alpha_{\mathrm{s}}$-casein is 0.240 ; (d) 75C cheese. SEM for $\gamma$-casein is 0.066 , SEM for $\beta$-casein is 0.161 , and SEM for $\alpha_{\mathrm{s}}$-casein is 0.154 ; (e) $100 \mathrm{C}$ cheese. SEM for $\gamma$-casein is 0.130 , SEM for $\beta$-casein is 0.409 , and SEM for $\alpha_{\mathrm{s}}$-casein is 0.258 .

Table 6. Mean values (from nine panellists), and corresponding standard deviation, of organoleptic evaluation of Picante cheese manufactured with different compositions of ovine and caprine milks by 180 days of ripening

\begin{tabular}{|c|c|c|c|c|c|}
\hline \multirow[t]{2}{*}{ Type of cheese } & \multicolumn{4}{|c|}{ Organoleptic parameters } & \multirow[t]{2}{*}{ Total } \\
\hline & Surface $(0-4)$ & Form $(0-4)$ & Texture $(0-6)$ & Flavour $(0-6)$ & \\
\hline $0 \mathrm{C}$ & $3.44 \pm 0.73$ & $3.22 \pm 0.94$ & $4.06 \pm 0.77$ & $4.22 \pm 1.00$ & $14.94 \pm 1.79$ \\
\hline $25 \mathrm{C}$ & $3.56 \pm 0.54$ & $3.22 \pm 0.71$ & $4.06 \pm 0.58$ & $4.00 \pm 1.25$ & $14.83 \pm 2.00$ \\
\hline $50 \mathrm{C}$ & $3.50 \pm 0.61$ & $3.67 \pm 0.43$ & $4.11 \pm 0.96$ & $4.61 \pm 0.78$ & $15.89 \pm 1.78$ \\
\hline $75 \mathrm{C}$ & $3.44 \pm 0.73$ & $3.56 \pm 0.60$ & $4.72 \pm 1.37$ & $4.72 \pm 0.72$ & $16.44 \pm 1.80$ \\
\hline $100 \mathrm{C}$ & $3.22 \pm 0.71$ & $2.83 \pm 0.70$ & $5.11 \pm 1.27$ & $4.78 \pm 0.81$ & $15.94 \pm 1.72$ \\
\hline
\end{tabular}




\section{ACKNOWLEDGEMENTS}

The authors are grateful to the members of the technical board of the Governmental Directorate of Agriculture of the Region of Beira Interior (DRABI, Portugal) for their cooperation in supervising the local manufacture of cheeses according to the experimental design selected and in transporting such cheeses to the ESB premises. The authors are also grateful to the members of OVIBEIRA for their cooperation in performance of the sensorial analysis. Financial support for author A. C. F. was provided by a Ph.D. Fellowship, BD/2111/92-IF, within the Programme for the Creation of National Infrastructures in Applied Science and Investigation (CIENCIA) administered by the National Board for Scientific and Technological Investigation (JNICT, Portugal). Partial financial support for the research expenses was provided by project 'MAQUETTE: Improvement of traditional cheeses and their technology', administered by the Innovation Agency (AI, Portugal) and by project 'PROTOLACTIS: Production, via optimized technologies, of traditional dairy products from certified sources', administered by PAMAF-IED (INIA, Portugal). The careful and critical reading of the original manuscript by Prof. Patrick Fox, c/o University College Cork (Ireland), is also gratefully acknowledged.

\section{REFERENCES}

Abo El-Ella, W. M., Abdel Baky, A. A., Aly, M. E. \& Fox, P. F. (1988). Effect of ripening temperature on proteolysis and lipolysis in outer and inner regions of Ras-type cheese made by various salting methods. Food Chem., 28, 1-16.

Adler-Nissen, J. (1979). Determination of the degree of hydrolysis of food protein hydrolysates by trinitrobenzenesulfonic acid. J. Agric. Food Chem., 6, 1256-1262.

Alichanidis, E., Anifantakis, E., Polychroniadou, A. \& Nanou, M. (1984). Suitability of some microbial coagulants for Feta cheese manufacture. J. Dairy Res., 51, 141-147.

Andrews, A. T. (1983). Proteinases in normal bovine milk and their action on caseins. J. Dairy Res., 50, 45-55.

Anonymous (1975). Fromages. Determination de la teneur en matière grasse. ISO 3433.

AOAC (1990). Acidity of cheese: Titrimetric method (970.124). In Official Methods of Analysis, vol. 2 - Food composition: additives and natural contaminants, pp. 842843.

Ardö, Y. \& Meisel, H. (1991). Methods for direct measurement of peptide bond cleavage in cheese. Int. Dairy Fed. Bull., 261, 10-13.

Assenat, L. (1985). Lait de brebis. Composition et propriétes. In Laits et Produits Laitiers, Vol. 1, ed. F. M. Luquet. Technique et Documentation Lavoisier, Paris.

Blakesley, R. W. \& Boezi, J. A. (1977). A new staining technique for proteolysis in polyacrylamide gels using Coomassie Brilliant Blue G-250. Anal. Biochem., 82, 580-581.

Cruz, A. A. (1945). Lacticínios da Beira Baixa: queijo à ovelheira e queijo à cabreira. Bol. Pecu. Lisboa, 12, 55-100.

de Jong, L. (1977). Protein breakdown in soft cheese and its relation to consistency. 2. The influence of the rennet concentration. Neth. Milk Dairy J., 31, 314-327.
Desmazeaud, M. J. \& Gripon, J. C. (1977). General mechanism of protein breakdown during cheese ripening. Milchwissenschaft, 32, 731-734.

Doi, E., Shibata, D. \& Matoba, T. (1981). Modified colorimetric ninhydrin methods for peptidase assay. Anal. Biochem., 118, 173-184.

Farkye, N. Y. \& Fox, P. F. (1990). Objective indices of cheese ripening. Trends Food Sci. Technol., 1, 37-40.

Farkye, N. Y., Kiely, L. Y., Allshouse, R. D. \& Kindstedt, P. S. (1991). Proteolysis in Mozarella cheese during refrigerated storage. J. Dairy Sci., 74, 1433-1448.

Fernández-Salguero, J., Marcos, A., Alcalá, M. \& Esteban, M. A. (1989). Proteolysis of Cabrales cheese and other European blue vein cheese varieties. J. Dairy Res., 56, 141145.

Folkertsma, B. \& Fox, P. F. (1992). Use of Cd-ninhydrin reagent to assess proteolysis in cheese during ripening. $J$. Dairy Res., 59, 217-224.

Fontecha, J., Peláez, C., Juárez, M., Requena, T. \& Gómez, C. (1990). Biochemical and microbiological characteristics of artisanal hard goat's cheese. J. Dairy Sci., 73, 1150-1157.

Fontecha, J., Peláez, C. \& Juárez, M. (1994). Biochemical characteristics of a semi-hard ewe's milk cheese. $Z$. Lebensm. Unters. Forsch., 198, 24-28.

Fox, P. F. (1989). Proteolysis during cheese manufacture and ripening. J. Dairy Sci., 72, 1379-1400.

Freitas, A. C. \& Malcata, F. X. (1996). Influence of milk type, coagulant, salting procedure and ripening time on the final characteristics of Picante cheese. Int. Dairy J., 6, 10991116.

Freitas, A. C., Sousa, M. \& Malcata, F. X. (1995). Effect of ripening time and the combination of ewe and goat milk on the microflora of Picante cheese. Ital. J. Food Sci., 7, 361-377.

Freitas, A. C., Pais, C., Malcata, F. X. \& Hogg, T. A. (1996). Microbiological characterization of Picante da Beira Baixa cheese. J. Food Protect., 59, 155-160.

Furtado, M. M. \& Partridge, J. A. (1988). Characterization of nitrogen fractions during ripening of a soft cheese made from ultrafiltration retentates. J. Dairy Sci., 71, 2877-2884.

González de Llano, D., Ramos, R. \& Martín-Alvarez, P. J. (1993). Comparative study of different methods for evaluating proteolysis in Blue cheese. Z. Lebensm. Unters. Forsch., 196, 29-31.

Grufferty, M. B. \& Fox, P. F. (1988a). Milk alkaline proteinase. J. Dairy Res., 55, 609-630.

Grufferty, M. B. \& Fox, P. F. (1988b). Factors affecting the release of plasmin activity from casein micelles. $N . Z . J$. Dairy Sci. Technol., 23, 153-163.

Guinee T. P. \& Fox, P. F. (1993). Salt in cheese: physical, chemical and biological aspects. In Cheese: Chemistry, Physics and Microbiology, ed. P. F. Fox. Chapman and Hall, London, pp. 257-302.

Guinee, T. P. \& Wilkinson, M. G. (1992). Rennet coagulation and coagulants in cheese manufacture. J. Soc. Dairy Technol., 45, 94-104.

Ibáñez, F. C., Torres, M. I., Ordónez, A. I. \& Barcina, Y. (1995). Effect of composition and ripening on casein breakdown in Idiazábal cheese. Chem. Mikrabiol. Technol. Lebensm., 17, 37-44.

Jarrett, W. D., Aston, J. W. \& Dulley, J. R. (1982). A simple method for estimating free amino acids in Cheddar cheese. Aust. J. Dairy Technol., 37, 55-58.

Jaubert, A. \& Martin, P. (1992). Reverse-phase HPLC analysis of goat caseins. Identification of $\alpha_{\mathrm{s} 1}$ and $\alpha_{\mathrm{s} 2}$ genetic variants. Lait, 72, 235-247.

Kleter, G. (1977). The ripening of Gouda cheese made under strictly asseptic conditions. II. The comparisons of the activity of different starters and the influence of certain lactobacilli strains. Neth. Milk Dairy J., 31, 177-187. 
Kosikowski, F. V. (1982). Cheese and Fermented Milk Foods. Edwards Brothers, New York, pp. 560-597.

Kuchroo, C. N. \& Fox, P. F. (1982). Soluble nitrogen in Cheddar cheese: comparison of extraction procedures. Milchwissenschaft, 37, 331-335.

Mallatou, H., Pappas, C. P. \& Voutsina, L. P. (1994). Manufacture of Feta cheese from sheep's milk, goat's milk or mixtures of these milks. Int. Dairy J., 4, 641-664.

Marcos, A., Esteban, M. A., León, F. \& Fernández-Salguero, J. (1978). Electrophoretic patterns of European cheeses: comparison and quantitation. J. Dairy Sci., 62, 892-900.

Marcos, A., Esteban, M. A. \& Fernández-Salguero, J. (1976). Influence of some chemical and physical factors on the proteolysis of cheese caseins. Arch. Zootec., 25, 73-86.

Mora, T. \& Marcos, A. (1981). Proteolysis in Manchego cheese: casein breakdown and their insoluble degradation products. Arch. Zootec., 30, 139-155.

Noomen, A. (1978). Activity of proteolytic enzymes in simulated soft cheeses (Meschanger type) 1. Activity of milk protease. Neth. Milk Dairy J., 32, 26-49.

O'Keeffe, A. M., Fox, P. F. \& Daly, C. (1978). Proteolysis in Cheddar cheese: role of coagulant and starter bacteria. $J$. Dairy Res., 45, 465-477.

Pappas, C. P., Kondyli, E., Voutsinas, L. \& Mallatou, H. (1992). Final Report of Research Project on Moisture control in Feta cheese. Ministry of Industry, Energy and Technology, Athens.

Pappas, C. P., Kondyli, E., Voutsinas, L. P. \& Mallatou, H. (1994). Effect of standardization of ewe's milk for casein/fat ratio on the composition, organoleptic and rheological properties of Feta cheese. Int Dairy J., 4, 763-778.

Remeuf, F. \& Lenoir, J. (1986). Relationship between the physico-chemical characteristics of goat's milk and its rennetability. Int. Dairy Fed. Bull., 202, 68-72.

Richardson, G. H. (Ed.) (1985). Standard Methods for the Examination of Dairy Products. American Public Health Association, Washington, DC.
Richardson, B. C. \& Pearce, K. N. (1981). The determination of plasmin in dairy products. N. Z.J. Dairy Sci. Technol., 16, 209-220.

Schlesser, J. E., Schmidt, S. J. \& Speckman, R. J. (1992) Characterization of chemical and physical changes in Camembert cheese during ripening. J. Dairy Sci., 75, 17531760.

Schroeder, C. L., Bodyfelt, F. W., Wyatt, C. J. \& McDaniel, M. R. (1988). Reduction of sodium chloride in Cheddar cheese: effect on sensory, microbiological, and chemical properties. J. Dairy Sci., 71, 2010-2020.

Simos, E., Voutsinas, L. P. \& Pappas, C. P. (1991). Composition of milk native Greek goats in the region of Metsovo. Small Ruminant Res., 4, 47-60.

Visser, F. M. W. (1977a). Contribution of enzymes from rennet, starter bacteria and milk to proteolysis and flavour development in Gouda cheese. 1. Description of cheese and asseptic cheesemaking techniques. Neth. Milk Dairy J., 31, 120-133.

Visser, F. M. W. (1977b). Contribution of enzymes from rennet, starter bacteria and milk to proteolysis and flavour development in Gouda cheese. 2. Development of bitterness and cheese flavour. Neth. Milk Dairy J., 31, 188209.

Visser, F. M. W. (1977c). Contribution of enzymes from rennet, starter bacteria and milk to proteolysis and flavour development in Gouda cheese. 3. Protein breakdown: analysis of the soluble nitrogen and amino acid nitrogen fraction. Neth. Milk Dairy J., 31, 210-239.

Wilkinson, M. G., Guinee, T. P., O'Callaghan, D. M. \& Fox, P. F. (1992). Effects of commercial enzymes on proteolysis and ripening in Cheddar cheese. Lait, 72, 449 459.

Zorrilla, S. E. \& Rubiolo, A. C. (1991). Average $\mathrm{NaCl}$ concentration in cheese for different volume ratios of brine and solid during salting. J. Food Sci., 56, 15481551. 